УДК 159.923 .32

doi: $10.15330 /$ ps.10.1.89-99

Наталія Савелюк

Кременецька обласна гуманітарно-педагогічна академія ім. Тараса Шевченка nsavelyuk@ukr.net

\title{
ЦІННІСНО-СМИСЛОВІ ПРОФІЛІ ОСОБИСТОСТІ НА РІЗНИХ РІВНЯХ РЕЛІГІЙНОЇ АКТИВНОСТІ: УНІВЕРСАЛЬНЕ Й ДИФЕРЕНЦІЮВАЛЬНЕ
}

У статті теоретично аналізується поняття «особистісний профіль» та емпірично доповнюються иіннісно-смислові виміри його конструювання. Використаний у дослідженні психодіагностичний інструментарій склали: «Питальник релігійної активності» Д. Смірнова, «Експрес-діагностика сочіальних иінностей» Н. Фетіскіна, В. Козлова, Г. Мануйлова та «Шістнадиять особистісних факторів» Р. Кеттела. Математична обробка кількісних даних здійснювалася із застосуванням t-критерію Ст 'юдента та факторного аналізу методом головних компонент. Через вирахування квартилів первинну вибірку респондентів поділено на чотири підгрупи з різними - від найнижчого до найвищого - рівнями релігійної активності.

В емпіричному дослідженні встановлені наступні пріоритетні соціальні цінності: на найнижчому рівні релігійної активності - вдале одруження/заміжжя, проводження часу в колі сім '̈ та декілька близьких друзів; на нижчому за середній рівні - проводження часу в колі сім $і$, вдале одруження/заміжжя та декілька близьких друзів; на вищому за середній рівні - проводження часу в колі сім'ї, вдале одруження/заміжжя та релігія, а на найвищому - релігія, проводження часу в колі сім 'ї та розмірковування про Бога, молитви. Констатовано, щуо на вищих рівнях релісійної активності найбільш істотно посилюється значущіссть релігійних цінностей, а також цінностей спілкування з рідними та близькими друзями, волонтерства, інтелектуального саморозвитку та здорового харчування, меншою мірою - спортивних вправ, залучення у суспільну діяльність і знайомства з новими людьми. Істотною мірою не змінюється суб 'єктивна привабливість захопливої роботи/навчання, вдалого одруження/заміжжя та кар 'єри.

Універсальною характеристикою особистісних ијннісно-смислових профілів $i$ низькорелігійних, $i$ високорелігійних суб'єктів визначено більше тяжіння критично мислячих $i$ ліберально налаштованих особистостей до здобуття високого соціального та матеріального статусу. Диференціювальними особливостями - відмінні на різних рівнях релігійної активності предиктори прагнення особистості до інтелектуального самовдосконалення, а також ії більшої спрямованості на вузькоособистісні або розлогі соціальні контакти.

Ключові слова: особистісний профіль, ијнності, релігійна активність, релігійні цінності.

Вступ. У сучасному соціумі особистість $є$ ще більш поліаспектною, нестабільною та «мозаїчною», аніж ще навіть десять-двадцять років тому. Так, віртуальна реальність, яка стрімко увірвалася у колись начебто об'єктивну та єдину нашу реальність, дедалі помітніше розмиває межі між поцей- та потойбічним світами, між досвідними та трансцендентними сутностями. Усе це неодмінно позначається на специфіці функціонування не тільки, наприклад, економічної, політичної, а й релігійної особистості. При цьому, як можна стверджувати, змінюються не стільки століттями кристалізовані консервативноаксіологічні засади ії буття, скільки унікальне осмислення цих засад у плинних вимірах конкретної ситуації та конкретного суб'єкта активності.

Постановка наукової проблеми та її значення. Психологічне дослідження ціннісно-смислових векторів релігійної особистості - актуальне наукове завдання. Мабуть, іще від Середньовіччя й до наших днів побутує стереотип, що суб'єкт релігійної віри переважно «темна», некритично мисляча людина, котра перебуває на зниженому рівні інтелектуального розвитку й повинна змушувати себе відмовлятися чи не від більшості звичних для інших «земних утіх». У зв'язку з цим настановленням громадська думка часто безапеляційно оцінює уявну канонічність або неканонічність поведінки священнослужителів, монахів або просто церковних прихожан. I тут, як і в багатьох інших соціальних ситуаціях, з поля уваги узагалі втрачаються або надто слабко усвідомлюються реальні психологічні чинники зовнішньої поведінки, дій, вчинків будь-якої особистості.

Один із вагомих таких чинників - ціннісно-смислові утворення психіки. Зауважмо, між іншим, що в Україні упродовж останніх десятиріч під керівництвом 3. С. Карпенко постала і плідно функціонує відповідна наукова школа - аксіологічна психологія особис- 
тості. У форматі їі теоретико-методологічних засад досліджуються психологічні особливості розвитку творчих здібностей дошкільників, становлення моральності молодших школярів, ціннісного самовизначення старшокласників, професійного самовизначення та здобуття вищої освіти студентською молоддю, перфекціоністських настанов майбутніх психологів, гуманізації професійної підготовки соціальних педагогів, профілактики «професійного вигорання» вчителя, оптимізації міжособистісних стосунків у педагогічному колективі, самоактуалізації сучасної жінки, вибору копінг-стратегій, трансформації механізмів психологічного захисту особистості та становлення іiі автентичності тощо [5]. Власне, окремих ціннісно-смислових векторів становлення релігійної (християнської) особистості торкається у своїх розвідках О. I. Климишин [6]. А проте, поряд з усіма фундаментальними теоретичними напрацюваннями, спроби чіткої емпіричної типологізації релігійності, пов'язаної із психодіагностичним конструюванням особистісних профілів,у нашій психології досі не здійснено.

Аналіз останніх досліджень із цієї проблеми. Поняття «профіль особистості» найбільш чітко виражається через дві дефініщії: 1) стислий опис особистості або індивідуальності та 2) метод презентування результатів психологічного тестування у графічній формі [11]. Перше визначення, таким чином, актуалізує необхідність оперативного (швидкісного) вербального аналізу особистісних рис, а друге - умову зручності візуалізації даних іï психодіагностування.

За кордоном використання відповідного поняття у психологічних дослідженнях $є$ доволі розлогим: від класичної проблематики прогнозування споживацької поведінки [12] до актуальних аспектів політичної психології [10].

В український науці поняття особистісного профілю використовується переважно в контексті вивчення патопсихологічних або межових психічних станів: хворих на параноїдну форму шизофренії [1], старших дошкільників із системними порушеннями мовлення [8], самоставлення студентів із високим рівнем особистісної безпорадності [3], невротичних схильностей та внутрішньої картини здоров'я у студентів [4], гендерних особливостей студентів із непсихотичними психічними розладами [7] та ін. Й лише окремі вітчизняні дослідження особистісного профілю стосуються проблематики здорового, адаптивного або нададаптивного функціонування: наприклад, специфіки творчої особистості [9] або усвідомлюваної саморегуляції поведінки майбутніх педагогів [2] та ін.

Як основні складові відповідного профілю виокремлюються, наприклад, невротичність, спонтанна агресивність, депресивність, дратівливість, комунікабельність, урівноваженість, реактивна агресивність, сором'язливість, відкритість, екстра-інтроверсія, емоційна лабільність, маскулінність-фемінність (згідно із «Фрайбурзьким багатофакторним опитувальником особистості (FPI)») або фізичне здоров'я, психологічне здоров'я, рівень незалежності особистості, здоров'я у соціальних взаєминах, здоров'я у відносинах із навколишнім середовищем, духовне здоров'я (згідно 3 «Питальником Якості Життя (ВОЗКЖ - 100)», розробленим ВООЗ), та ін.

Одним з індикаторів духовного здоров'я особистості, між іншим, визначається іï здатність до переживання релігійних почуттів [4, с. 81]. Назагал виникає низка запитань щодо гіпотетичних кореляцій релігійності не тільки з вищими - духовними якостями, а й 3 усіма іншими рисами особистості.

Так, новітні закордонні дослідження, проведені в рамках концептуальної особистісної моделі «Великої П'ятірки» на респондентах із 19 країн світу, продемонстрували, згідно з даними В. Сароглоу, універсальну схильність релігійних особистостей до «залученості (екстраверсіі)» («фактор А») й до «сумлінності (надійності)» («фактор С»). Стверджується також, що з іншими трьома базовими рисами («доброзичливістю», «емоційною стабільністю» та «відкритістю до досвіду») релігійність не корелює [13].

В цілому, якщо зіставляти результати різних дослідників, взаємозв'язки між релігійністю й базовими особистісними рисами - нелінійні й неоднозначні. По-перше, дані окремих емпіричних розвідок нерідко не збігаються або й навіть суперечать одні одним; 
по-друге, релігійна особистість розглядається переважно як застигла система, поза врахуванням реальних диференціацій у рівнях розвитку та проявів релігійності; й, по-третє, більшість емпіричних досліджень були проведені в інших країнах, соціокультурне середовище яких істотно відрізняється від української ментальності.

Формулювання мети та завдань статті. 3 огляду на вище викладене, в нашому дослідженні ми поставили основну мету емпірично виокремити й описати ціннісносмислові особистісні профілі суб'єктів із різними рівнями релігійної активності. Завдання статті: 1) теоретично проаналізувати поняття «особистісний профіль» та «релігійна активність», 2) виокремити кореляційні плеяди між цінностями й базовими особистісними рисами на різних рівнях релігійної активності, 3) емпірично обгрунтувати універсальне та специфічне у ціннісно-смисловій сфері особистості на різних рівнях релігійної активності.

В нашому дослідженні ми будемо опиратися на розуміння релігійної активності як інтегративної форми активності такої особистості, котра періодично переживає певні сакральні, дуже часто інтуїтивні, ірраціональні емоційні процеси та стани, приймає за істинні певні релігійні уявлення та поняття, усвідомлює та реалізує релігійно релевантні потреби, мотиви, інтенції, а також здійснює відповідні усім цим внутрішнім почуттям, уявленням, мотивам, інтенціям і зовнішнім релігійним нормам дії та вчинки.

Методи та методики. Сформована на засадах добровільної участі у дослідженні вибірка склала 543 особи різного віку, соціального статусу та з різних регіонів Західної України. Вона $є$ репрезентативною щодо конфесійної структури сучасного українського суспільства (християнської його частини), а також у контексті співвідношення міського та сільського населення, осіб із різними ступенями освіти тощо.

На першому етапі емпіричного дослідження використано «Питальник релігійної активності» Д. Смірнова, що складається із чотирьох субтестів - шкал. Кожне з його запитань передбачає по чотири варіанти відповідей (від «ніколи» до «дуже часто»), які надалі піддаються переведенню у чотирибальну систему оцінювання (від 1 до 4 балів). Перший субтест («Шкала релігійних переживань») містить 36 запитань, другий («Шкала внутрішньої/зовнішньої релігійної мотивації») та третій («Шкала релігійного/природничо-наукового світогляду») субтести - по 11 пунктів, а четвертий («Шкала релігійних дій») - 10 запитань. Загалом, таким чином, за усіма шкалами потенційно респондент максимально може набрати 272 бали.

Методом вирахування квартилів усю початкову вибірку поділено на чотири підгрупи: перша - 138 осіб із найнижчим рівнем релігійної активності, друга - 141 особа 3 рівнем релігійної активності, нижчим за середній, третя - 139 осіб із рівнем релігійної активності, вищим за середній, та четверта - 125 осіб із найвищим рівнем релігійної активності.

На другому етапі дослідження використана методика «Експрес-діагностика соціальних цінностей особистості» Н. Фетіскіна, В. Козлова, Г. Мануйлова. Вона дає змогу продіагностувати рівень суб'єктивної значущості основних соціальних цінностей особистості: суспільних, сімейних, фінансових, професійних, фізичних, інтелектуальних і, зокрема, релігійних. 3 цією метою респондентам пропонується оцінити 16 тверджень за шкалою від 1 бала («зовсім неважливо») через 5 балів («сумніваюся, чи важливо») до максимальних 10 балів («дуже важливо»).

А на третьому етапі дослідження ми скористалися достатньою мірою апробованим i популярним питальником «Шістнадцять особистісних факторів (16-PF)» Р. Кеттела. За результатами відповідної методики можна будувати, власне, кількісний та візуальний профіль особистості, при інтерпретації якого увага приділяється, насамперед, його «пікам» - тобто найбільш низьким і найбільш високим значенням факторів, відображених у стенах (особливо тим, які є або нижчими за показник у 3 стени, або вищими за 7 стенів).

3 метою смислової інтеграції та більш системної інтерпретації отриманих результатів, отримані кількісні показники були піддані процедурі факторного аналізу (за допомогою програми «SPSS», версії 17.0) - окремо для кожної підгрупи й спільно за двома 
останніми методиками (психодіагностування соціальних цінностей та 16 базових особистісних рис). Факторизація масиву емпіричних даних здійснювалася методом головних компонент, використовувалося варімакс-обертання первинно отриманої факторної структури до досягнення іiі оптимальності. Для виокремлення найбільш значущих факторів узято критерій Кайзера, а до складу певної структури включалися тільки ті шкали, показники факторних навантажень яких більші за 0,4 [14, с. 394].

Виклад основного матеріалу й обгрунтування отриманих результатів дослідження. Як зазначено вище, за результатами застосування першої методики й вирахування квартилів уся первинна вибірка була поділена на чотири підгрупи з різними рівнями релігійної активності. Інакше кажучи, надалі ми розглядатимемо поняття «релігійність» не як певну абсолютну характеристику абстрактного суб'єкта релігійної віри, а як диференційовану за своїми проявами якість, співвідносну з конкретними особистісними рисами.

За результатами застосування другої методики продіагностовані та співставлені кількісні виміри (оцінки) суб'єктивної значущості різних соціальних цінностей співвідносно з рівнями релігійної активності респондентів (табл. 1):

Таблиия 1

Рангові й усереднені показники міри значущості соціальних цінностей для суб'сктів із різними рівнями релігійної активності (РА)

\begin{tabular}{|c|c|c|c|c|c|c|}
\hline $\begin{array}{l}\text { № } \\
\text { 3/II }\end{array}$ & Цінність & $\begin{array}{c}\text { Най- } \\
\text { нижчий } \\
\text { рівень PA } \\
(\text { ранг / Х) }\end{array}$ & $\begin{array}{c}\text { Нижчий за } \\
\text { середній } \\
\text { рівень PA } \\
(\text { ранг / } \bar{x})\end{array}$ & $\begin{array}{l}\text { Вищий за } \\
\text { середній } \\
\text { рівень PA } \\
(\text { ранг } / \bar{x})\end{array}$ & $\begin{array}{c}\text { Най-вищий } \\
\text { рівень РА } \\
(\text { ранг / х) }\end{array}$ & $\begin{array}{c}\text { Серед. } \\
\text { показн. } \\
\text { (по } \\
\text { вибірці) } \\
\end{array}$ \\
\hline 1. & $\begin{array}{l}\text { Проводження часу в } \\
\text { колі сім’ } \dddot{1}\end{array}$ & $2 / 8,49$ & $1 / 8,99$ & $1 / 9,38$ & $2 / 9,23$ & 9,02 \\
\hline 2. & $\begin{array}{l}\text { Вдале } \\
\text { одруження/заміжжя }\end{array}$ & $1 / 8,62$ & $2 / 8,39$ & $2 / 8,84$ & $5 / 8,90$ & 8,69 \\
\hline 3. & $\begin{array}{l}\text { Декілька } \\
\text { друзів }\end{array}$ & $3 / 8,30$ & $3 / 8,25$ & $4 / 8,55$ & $4 / 8,93$ & 8,51 \\
\hline 4. & Релігія & $10 / 6,21$ & $5 / 7,88$ & $3 / 8,80$ & $1 / 9,46$ & 8,09 \\
\hline 5. & $\begin{array}{l}\text { Високооплачувана } \\
\text { робота }\end{array}$ & $4 / 8,25$ & $4 / 8,08$ & $7 / 8,14$ & $8 / 7,73$ & 8,05 \\
\hline 6. & $\begin{array}{l}\text { Інтелектуальний } \\
\text { розвиток }\end{array}$ & $6 / 7,96$ & $7 / 7,67$ & $6 / 8,19$ & $6 / 8,35$ & 8,04 \\
\hline 7. & $\begin{array}{l}\text { Захоплива } \\
\text { робота/навчання }\end{array}$ & $5 / 7,99$ & $6 / 7,78$ & $8 / 7,97$ & $7 / 8,02$ & 7,94 \\
\hline 8. & $\begin{array}{l}\text { Розмірковування про } \\
\text { Бога, молитви }\end{array}$ & $16 / 5,35$ & $8 / 7,39$ & $5 / 8,38$ & $3(2) / 9,23$ & 7,59 \\
\hline 9. & $\begin{array}{l}\text { Знайомство з новими } \\
\text { людьми, соціальні } \\
\text { заходи }\end{array}$ & $7 / 7,68$ & $10 / 6,84$ & $10 / 7,06$ & $9 / 7,19$ & 7,19 \\
\hline 10. & Kap'єра & $8 / 7,37$ & $9 / 6,94$ & $9 / 7,21$ & $10 / 7,04$ & 7,14 \\
\hline 11. & $\begin{array}{lr}\text { Читання } & \text { просвітни- } \\
\text { цької } & \text { літератури, } \\
\text { перегляд телепередач }\end{array}$ & $12 / 5,84$ & $11 / 6,32$ & $11 / 6,78$ & $11 / 6,93$ & 6,46 \\
\hline 12. & Волонтерство & $13 / 5,75$ & $14 / 5,57$ & $12 / 6,45$ & $12 / 6,70$ & 6,12 \\
\hline 13. & Спортивні вправи & $11 / 5,88$ & $13 / 5,63$ & $14 / 6,12$ & $14 / 6,33$ & 5,99 \\
\hline 14. & $\begin{array}{l}\text { Красиві машини, } \\
\text { одяг, будинок }\end{array}$ & $9 / 6,25$ & $12 / 6,08$ & $16 / 5,92$ & $16 / 5,59$ & 5,96 \\
\hline 15. & $\begin{array}{l}\text { Залучення у суспіль- } \\
\text { ну діяльність }\end{array}$ & $14 / 5,58$ & $15 / 5,50$ & $13 / 6,26$ & $15 / 6,10$ & 5,86 \\
\hline 16. & Здорова дієта & $15 / 5,41$ & $16 / 5,41$ & $15 / 6,01$ & $13 / 6,40$ & 5,81 \\
\hline
\end{tabular}

Як бачимо за даними таблиці, універсально пріоритетною для всіх респондентів цінністю, фактично незалежною від впливу їх релігійної активності, є «проводження часу 
в колі сім’і», яка в усіх підгрупах посідає перше або друге рангові місця із середніми показниками від 8,49 до 9,38. Також дуже значущим у всіх підгрупах, займаючи перший або другий ранги (за винятком останньої підгрупи - п’ятий ранг), є «вдале одруження/заміжжя». Цінність «декілька близьких друзів», посідаючи третю рангову позицію у першій та другій підгрупах, посувається на четверту - в двох останніх підгрупах. А проте, усереднені показники - від 8, 25 до 8,93 у всіх підгрупах, вказують на ії вагому особистісну значущість для респондентів із різними рівнями релігійної активності.

Найбільш яскравою є встановлена динаміка цінності релігії: посідаючи лише десяте місце у першій підгрупі $(\overline{\mathrm{x}}=6,21)$, у другій вона стає п'ятою $(\overline{\mathrm{x}}=7,88)$, у третій третьою $(\overline{\mathrm{x}}=8,80)$, а у четвертій - вже першою $(\overline{\mathrm{x}}=9,46)$ за своєю значущістю. Також важливо зазначити, що «розмірковування про Бога, молитви», посідаючи лише останню шістнадцяту позицію $(\overline{\mathrm{x}}=5,35)$ у першій підгрупі, у четвертій фактично стають уже другими у загальній ієрархії $(\overline{\mathrm{x}}=7,39)$, поділяючи відповідне місце 3 вагомістю тісного родинного спілкування.

Крім того, незалежно від рівня релігійної активності, відносно найменш значущими соціальними цінностями виявилися: «залучення у суспільну діяльність» із ранговими позиціями від тринадцятої по шістнадцяту (середні показники - від 5,50 до 6,26, що вказує на істотні сумніви респондентів щодо ролі відповідної цінності у їх житті) та «здорова дієта», рангові показники якої майже в усіх підгрупах посіли останні дві позиції (середні показники - від 5,41 до 6,40 - теж балансують на межі індивідуального прийняття значущості).

Відобразимо отримане співвідношення усереднених показників цінностей у всіх підгрупах також у формі діаграми (рис. 1):

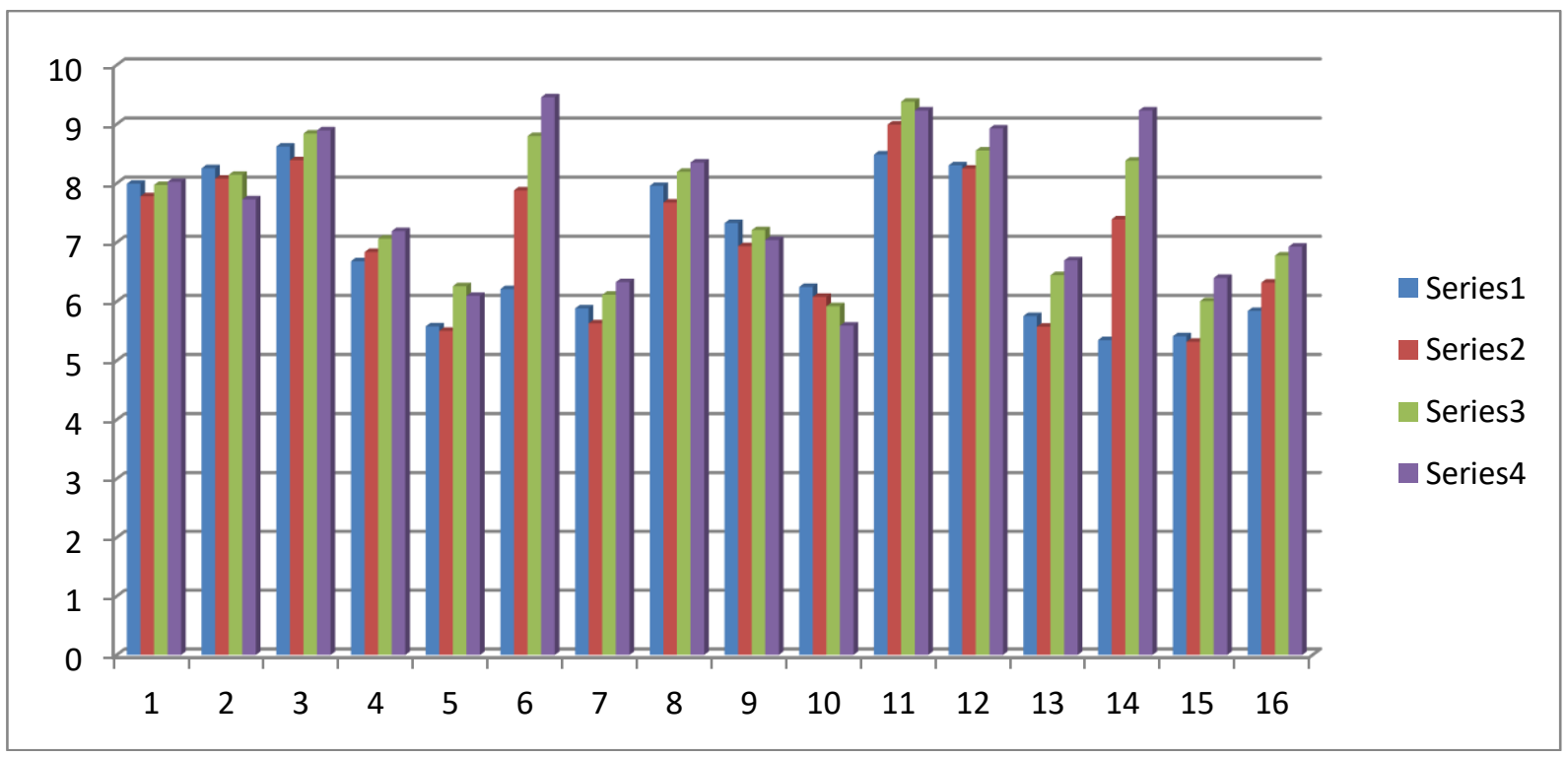

Рис. 1. Значущість соціальних цінностей на різних рівнях РА

Примітка: 1 - захоплива робота/навчання, 2 - високооплачувана робота, 3 - вдале одруження/заміжжя, 4 - знайомство з новими людьми, 5 - залучення у суспільну діяльність, 6 - релігія, 7 - спортивні вправи, 8 - інтелектуальний розвиток, 9 - кар'єра, 10 - красиві речі, 11 - проводження часу в сім'ї, 12 - декілька близьких друзів, 13 - волонтерство, 14 - розмірковування про Бога, 15 - здорова дієта, 16 - просвітництво; ряд 1 - у 1 підгрупі, ряд 2 - у 2 підгрупі, ряд 3 - у 3 підгрупі, ряд 4 - у 4 підгрупі.

Після вирахування середніх арифметичних показників і складання відповідних ієрархій, також визначалася міра статистичної значущості відмінностей в оцінках цінностей між підгрупами. Насамперед, із метою перевірки міри відповідності отриманих первинних емпіричних показників нормальному розподілу даних використовувався 
статистичний критерій однорідності Колмогорова-Смірнова. Й оскільки отримані значення критерію (від 2,42 до 7,60) виявилися меншими за критичне (при $\mathrm{p} \leq 0,001$ ), було констатовано, що емпіричний розподіл даних відповідає нормальному. Тому надалі 3 метою підтвердження або спростування прогнозованої наявності статистично значущих розбіжностей між оцінками цінностей у чотирьох підгрупах використовувався параметричний t-критерій Ст’юдента.

За даним критерієм визначено наступні статистично значущі відмінності:

1) між оцінками цінності «високооплачувана робота»- в 1-й та 4-й підгрупах (t-критерій $=2,01$ при $\mathrm{p}=0,05 ; \overline{\mathrm{x}}-8,25$ i 7,73); отже, значущість відповідної цінності істотно нівелюється для найбільш високорелігійних осіб лише порівняно з найменш релігійними у вибірці суб'єктами;

2) між оцінками цінності «знайомство 3 новими людьми» - теж тільки в 1-й та 4-й підгрупах (t-критерій $=1,98$ при $\mathrm{p}=0,05 ; \overline{\mathrm{x}}-8,39$ i 8,90); тут, навпаки, значущість даної цінності суттєво зростає для високорелігійних осіб;

3) між оцінками цінності «залучення у суспільну діяльність» - в 1-й та 3-й підгрупах (t-критерій $=2,74$ при $\mathrm{p}=0,006 ; \overline{\mathrm{x}}-5,58$ i 6,26), 2-й та 3-й підгрупах (t-критерій $=2,99$ при $\mathrm{p}=0,003 ; \overline{\mathrm{x}}-5,50$ і 6,26), 2-ій та 4-ій підгрупах (t-критерій $=2,13$ при $\mathrm{p}=0,03 ; \overline{\mathrm{x}}-5,50$ і 6,10$)$; тобто, майже синхронно зі зростанням релігійної активності зростає і значущість відповідної соціальної цінності;

4) між оцінками цінності «релігія» статистично значущі відмінності закономірно спостерігаються між усіма підгрупами: зокрема, навіть у 1-й та 2-й підгрупах (t-критерій = 6,33 при $\mathrm{p} \leq 0,001 ; \overline{\mathrm{x}}-6,21$ i 7,88), 3-й та 4-й (t-критерій $=3,68$ при $\mathrm{p} \leq 0,001 ; \overline{\mathrm{x}}-8,80$ i $9,46)$, а в 1-й та 4-й підгрупах вони є найяскравішими (t-критерій $=13,43$ при $\mathrm{p} \leq 0,001$; $\overline{\mathrm{x}}-6,21$ i 9,46$)$;

5) між оцінками цінності «спортивні вправи» - лише у 2-й та 4-й підгрупах (t-критерій $=2,25$ при $\mathrm{p}=0,03 ; \overline{\mathrm{x}}-5,63$ і 6,33);

6) між оцінками цінності «інтелектуальний розвиток»- - 2-й та 4-й підгрупах (t-критерій $=3,04$ при $\mathrm{p}=0,003 ; \overline{\mathrm{x}}-7,67$ i 8,35), 2-ій та 3-ій підгрупах (t-критерій $=2,46$ при $\mathrm{p}=0,02 ; \overline{\mathrm{x}}-7,67$ і 8,19); отже, спостерігається певна тенденція зростання суб'єктивної значущості зазначеної цінності на вищих рівнях релігійної активності;

7) між оцінками цінності «дорогі, красиві речі» - тільки в 1-й та 4-й підгрупах (tкритерій $=2,11$ при $\mathrm{p}=0,04 ; \overline{\mathrm{x}}-6,25$ i 5,59); таким чином, для високо релігійних респондентів значущість відповідної матеріальної цінності суттєво нівелюється, порівняно 3 найменш релігійними учасниками дослідження;

8) між оцінками цінності «проводження часу в сім'ї» - в 1-й та 3-й підгрупах (t-критерій $=5,19$ при $\mathrm{p} \leq 0,001 ; \overline{\mathrm{x}}-8,49$ і 9,23), 1-ій та 4-ій підгрупах (t-критерій $=3,75$ при $\mathrm{p} \leq 0,001 ; \overline{\mathrm{x}}-8,49$ i 9,23); отже, значущість зазначеної цінності істотно зростає на вищих рівнях релігійної активності;

9) між оцінками цінності «декілька близьких друзів» - в 1-й та 4-й підгрупах (t-критерій $=2,82$ при $\mathrm{p}=0,005 ; \overline{\mathrm{x}}-8,30$ і 8,93), у 2-ій та 4-ій підгрупах (t-критерій $=3,15$

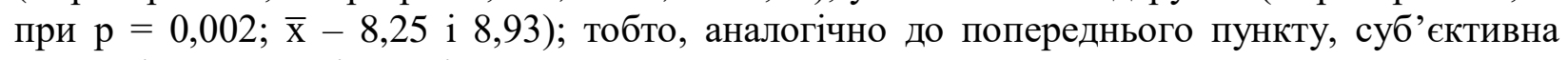
значущість даної цінності суттєво посилюється;

10) між оцінками цінності «волонтерство» - в 1-й та 4-й підгрупах (t-критерій = 3,30 при $\mathrm{p}=0,001 ; \overline{\mathrm{x}}-5,75$ і 6,70), 2-ій та 4-ій підгрупах (t-критерій $=3,55$ при $\mathrm{p} \leq 0,001$; $\overline{\mathrm{x}}-5,57$ i 6,70), 2-ій та 3-ій підгрупах (t-критерій $=3,40$ при $\mathrm{p}=0,001 ; \overline{\mathrm{x}}-5,57$ i 6,45); таким чином, спостерігається тенденція зростання значущості відповідної цінності синхронно зі збільшенням релігійної активності особистості;

11) між оцінками цінності «розмірковування про Бога» статистично значущі відмінності закономірно спостерігаються між усіма підгрупами: зокрема, навіть між 1-ю та 2-ю підгрупами (t-критерій $=7,97$ при $\mathrm{p} \leq 0,001 ; \overline{\mathrm{x}}-5,35$ і 7,39), між 3-ю та 4-ю (t-критерій $=4,23$ при $\mathrm{p} \leq 0,001 ; \overline{\mathrm{x}}-8,38$ i 9,23), а між 1-ою та 4-ою підгрупами $\epsilon$ найсуттєвішими (t-критерій $=16,22$ при $\mathrm{p} \leq 0,001 ; \overline{\mathrm{x}}-7,97$ i 9,23); 
12) між оцінками цінності «здорова дієта» статистично значущі відмінності також спостерігаються майже між усіма підгрупами: наприклад, між 1-ю та 4-ю (t-критерій = 3,19 при $\mathrm{p}=0,02 ; \overline{\mathrm{x}}-5,41$ i 6,40), між 2-ю та 3-ю (t-критерій $=2,19$ при $\mathrm{p}=0,03 ; \overline{\mathrm{x}}-5,32$ i $6,01)$ та ін.; тобто, синхронно зі зростанням релігійної активності увиразнюється й позитивне ставлення особистості до здорової, збалансованої дієти;

13) між оцінками цінності «просвітництво» - в 1-й та 4-й підгрупах (t-критерій = 3,50 при $\mathrm{p}=0,001 ; \overline{\mathrm{x}}-5,84$ і 6,93), 1-й та 3-й підгрупах (t-критерій $=3,15$ при $\mathrm{p}=0,002$; $\overline{\mathrm{x}}-5,84$ i 6,78), 2-й та 4-й підгрупах (t-критерій $=1,98$ при $\mathrm{p}=0,05 ; \overline{\mathrm{x}}-6,32$ і 6,93); таким чином, суб'єктивна значущість відповідної цінності суттєво зростає на двох вищих рівнях релігійної активності, що пов'язане, принаймні частково, 3 активнішим переглядом релігійної інформації.

Назагал, за підсумками проведеного аналізу, констатуємо, що на вищих рівнях релігійної активності найбільш істотно посилюється значущість релігійних цінностей (релігія, розмірковування про Бога та молитви), а також проводження часу з рідними, волонтерства, близьких друзів, інтелектуального саморозвитку та здорового харчування, меншою мірою - спортивних вправ, залучення у суспільну діяльність і знайомства 3 новими людьми. Водночас спадає міра значущості високооплачуваної роботи, але лише в контексті порівняння найбільш і найменш релігійних осіб. Натомість істотною мірою не змінюється суб'єктивна привабливість захопливої роботи/навчання, вдалого одруження/заміжжя та кар'єри. Інакше кажучи, ці три цінності $є$ автономними щодо рівня релігійної активності особистості.

Далі, як вже зазначалося, було застосовано процедуру факторного аналізу, що дало змогу виокремити не тільки ціннісні ієрархії, а власне ціннісно-смислові структури у респондентів із різними рівнями релігійної активності. А оскільки факторизація емпіричних даних проводилася на спільному масиві кількісних показників за другою та третьою із використаних методик, то мова вже може йти про ціннісно-смислові профілі особистості. Своєю чергою, останні дають змогу розглядати поведінку, дії, вчинки особистості 3 різними рівнями релігійної активності більш диференційовано.

Одразу зазначимо, що спільно із власне релігійними цінностями жодна із продіагностованих 16 базових особистісних рис у жодній із підгруп не увійшла у значущі факторні плеяди. Разом із тим, відповідні плеяди були утворені окремими такими рисами й деякими іншими соціальними цінностями особистості, що дає змогу стверджувати про певний вагомий взаємовплив між ними.

Зокрема, на найнижчому рівні релігійної активності виокремлені та проінтерпретовані наступні особистісні ціннісно-смислові структури:

1) однополюсна «Власний матеріальний добробут $і$ соиіальний статус» - високооплачувана робота $(0,83)$, красиві машини, одяг, будинок $(0,78)$, кар'єра $(0,58)$ та радикалізм $(0,47)$; отже, на даному рівні релігійної активності прагнення до матеріального добробуту й високого соціального статусу корелює з особистісною схильністю до радикалізму - експериментаторства, ліберальності, критичності, аналітичності мислення, недовіри до суспільних авторитетів й ін.;

2) двополюсна «Інтелектуальне домінування / Соціальна вишуканість у поведінųi», на першому полюсі якої - читання просвітницької літератури, перегляд телепередач $(0,52)$ та домінантність $(0,64)$, радикалізм $(0,52)$, а на другому - дипломатичність $(-0,69)$; спостерігаємо доволі цікаву тенденцію: чим більше низькорелігійний суб'єкт схильний до властолюбства, впертості й інтелектуального скептицизму, а також чим менш - до вишуканості та емоційної стриманості в соціальній поведінці, тим істотнішою мірою він тяжіє до інтелектуального самовдосконалення;

3) однополюсна «Підтримувальне інтимно-міжособистісне спілкування» - декілька близьких друзів $(0,71)$, проводження часу в колі сім'ї $(0,68)$ та висока самооцінка $(0,42)$, сила «Я» $(0,41)$; як бачимо, тяжінню до тісного інтимно-міжособистісного спілкування сприяє, з одного боку, високий самоконтроль, схильність до лідерства, цілеспря- 
мованість, з іншого боку, - емоційна стійкість, реалістичне налаштування, витримка, працездатність відповідних осіб;

4) двополюсна «Егоиентрична внутрішня мотивованість / Невпевненість у собi», на першому полюсі якої - захоплива робота/навчання, що приносить задоволення $(0,67)$ та протенсія $(0,56)$, на другому - гіпотимія $(-0,40)$; таким чином, суб'єктивна значущість задоволення від процесу роботи/навчання на даному рівні релігійної активності прямо пов'язана зі спрямованістю особистості на саму себе, іï замкненістю й недовірливістю до інших, а обернено пропорційно - 3 почуттям власної вини, невпевненості у собі, тривожності.

На нижчому за середній рівні релігійної активності виокремлені такі дві спільні факторні плеяди:

1) двополюсна «Соціальний успіх / Невпевненість у собі», на першому полюсі якої кар'єра $(0,45)$, дипломатичність $(0,68)$, високий інтелект $(0,62)$, на другому - гіпотимія $(-0,49)$; отже, схильності до кар'єризму у відповідних респондентів закономірно сприяють ïх високі розумові здібності та соціальна досвідченість, уміння тонко аналізувати різні ситуації, здатність до розуміння інших, тоді як перешкоджає - висока тривожність і невпевненість у собі;

2) двополюсна «Відданість іншим / Замкненість на собі», на першому полюсі якої - волонтерство $(0,53)$ та декілька близьких друзів $(0,49)$, на другому - протенсія $(-0,59)$; тобто, виникненню потягу до альтруїстичної діяльності й тісного спілкування на нижчому за середній рівні релігійної активності опонують ревнивість, замкненість, дратівливість як особистісні риси.

На вищэому за середній рівні реліzійної активності виокремлено також дві факторні структури:

1) однополюсна «Підтримувальна внутрішня мотивація діяльності» - захоплива робота/навчання, що приносить задоволення $(0,53)$ та високе «Супер-Его» $(0,77)$, висока самооцінка $(0,74)$, сила «Я» $(0,49)$; таким чином, у даній підгрупі прагнення до внутрішньо мотивованої діяльності прямо корелює із особистісною нормативністю, високим самоконтролем та емоційною стійкістю;

2) двополюсна «Прихильність здоровим груповим традиціям / Хвороблива усамітненість і сором'язливість», на першому полюсі якої - залежність від групи $(0,63)$, здорова дієта $(0,57)$, консерватизм $(0,40)$, на другому - афектотимія $(-0,66)$ та пармія $(-0,51)$; отже, знову спостерігається цікава тенденція: прагнення особистості з високим рівнем релігійної активності до здорового харчування взаємозв'язане із соціальбельністю, натомість негативно корелює - із соціофобічністю.

I на найвищзму рівні релігійної активності виокремлені такі особистісні категоріально-смислові структури:

1) двополюсна «Соціальна активність / Соціальна автономність», на першому полюсі якої - знайомство з людьми, соціальні заходи $(0,82)$, залучення у суспільну діяльність $(0,71)$, волонтерство $(0,53)$, на другому - самодостатність $(-0,42)$; тобто, міра соціальної замученості високорелігійної особистості обернено пропорційно корелює з розвитком iï особистісної автономності; інакше кажучи, соціальну активність такої особистості стимулює іiі висока залежність від групи;

2) однополюсна «Власний соичіальний статус і матеріальний добробут» - кар'єра $(0,76)$, красиві машини, одяг, будинок $(0,72)$, високооплачувана робота $(0,65)$ і радикалізм $(0,56)$; як можемо бачити, навіть на найвищому рівні релігійної активності високий

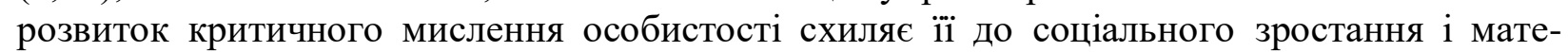
ріального накопичення тут - у земному світі;

3) однополюсна «Самодостатній інтелектуальний та фізичний розвиток»- читання просвітницької літератури, перегляд телепередач $(0,74)$, здорова дієта $(0,68)$, інтелектуальний розвиток $(0,58)$ та самодостатність $(0,42)$; отже, розвинена особистісна авто- 
номність стимулює високорелігійного суб'єкта до власного інтелектуального вдосконалення та підтримки фізичного здоров'я;

4) двополюсна «Тілесна досконалість / Розвинений соиіальний інтелект», на першому полюсі якої - спортивні вправи $(0,48)$, на другому - дипломатичність $(-0,74)$ і високий інтелект $(-0,61)$; тобто, ті високорелігійні особистості, котрі мають більш розвинений практичний інтелект і характеризуються прямотою своїх соціальних манер, більше схильні до фізичного, тілесного самовдосконалення.

Висновки та перспективи подальших досліджень. Отже, міра прояву тих або інших базових особистісних рис статистично значуще не корелює зі свідомим вибором або відхилянням релігійних цінностей як пріоритетних і вагомих у житті. Інакше кажучи, особистісні портрети суб'єктів із приблизно однаковою ціннісною орієнтованістю на релігію насправді суттєво відрізняються. Так, наприклад, високорелігійні суб'єкти можуть, наприклад, характеризуватися як яскравим конформізмом, так i, навпаки, не менш яскравим радикалізмом або як істотною залежністю від групи, так i помітною особистісною автономністю.

3 усім цим, у межах певного рівня релігійної активності та чи інша високорозвинена особистісна риса може визначати вибір певних інших соціальних цінностей як більш або менш пріоритетних. Зокрема, високорелігійні особистості, залежні від групи, більшою мірою схильні залучатися в соціальну активність, а самодостатні - інтелектуально самовдосконалюватися; схильні до радикалізму в поглядах і до активного інтелектуального пошуку, мабуть, шукають принаймні частковий вихід своєму життєвому експериментуванню в кар'єризмі, а особи з вагомішим практичним інтелектом і безпосередністю в поведінці більшою мірою надають перевагу фізичним вправлянням.

Універсальною характеристикою особистісних ціннісно-смислових профілів і низькорелігійних, і високорелігійних суб'єктів виступає тяжіння критично мислячих і ліберально налаштованих суб'єктів, котрі є на всіх рівнях релігійної активності, до здобуття високого соціального й матеріального статусу. Відповідно, чим більш консервативні погляди й цінності релігійної особистості, тим меншою мірою вона свідомо поціновуватиме кар'єризм і розкіш у житті.

Диференціювальною особливістю відповідних профілів у низькорелігійних та у високорелігійних суб'єктів виступають, між іншим, особистісні пре диктори прагнення до інтелектуального самовдосконалення: якщо для перших це -особистісне домінування над іншими, соціальна критичність і непоступливість, то для других - автентична особистісна незалежність, тобто фактично в останньому випадку це вже «свобода для...», а не «свобода від...».

Крім того, якщо однією із яскравих ціннісно-смислових структур низькорелігійних суб'єктів є їх налаштованість на вузькоособистісні й емоційно комфортні для них контакти, пов'язані з сильним особистісним «Я», то у високорелігійних - потяг до масштабнішої та альтруїстично орієнтованої соціальної активності, що корелює 3 їх більшою залежністю від групової підтримки та суспільного схвалення.

Перспективи подальших наукових досліджень вбачаємо в емпіричній побудові й порівнянні особистісних ціннісно-смислових профілів окремо для різних християнських гілок: православ'я, католицизму, протестантизму, а також для представників інших світових релігій.

1. Аймедов, К. В., Морванюк, Г. В. (2015). Типи особистісних профілів чоловіків та жінок, хворих на параноїдну форму шизофренії. Психіатрія, неврологія та медична психологія, 2, 1, 10-14.

2. Бутузова, Л. П., Сидоренко, Н. І. (2014). Особистісний профіль усвідомлюваної саморегуляції поведінки майбутніх педагогів. Наука і освіта. Психологія, 5, 116-121.

3. Демчук, О. А. (2016). Особистісний профіль самоставлення в структурі Я-концепції студентів із високим рівнем безпорадності. Психологічні перспективи, 28, 107-119.

4. Зотова, Л. М. (2012). Профіль невротичних схильностей як особистісний фактор, що визначає внутрішню картину здоров'я в студентів. Вісник Харківського наџіонального педагогічного університету імені Г. С. Сковороди. Психологія, 44 (1), 79-92. 
Франківськ

5. Карпенко, 3. (2018). Аксіологічна психологія особистості. 2-ге вид., перероб., доповн. Івано-

6. Климишин, О. І. (2010). Психологія духовності особистості: християнськи-орієнтований підхід. Івано-Франківськ: Гостинець.

7. Лещина, I. В. (2012). Гендерні особливості особистісного профілю у студентів з непсихотичними психічними розладами. Український вісник психоневрології, 20, 3, 193-194.

8. Мартиненко, I. В. (2015). Характеристика особистісного профілю старшого дошкільника 3 системними порушеннями мовлення. Науковий часопис Національного педагогічного університету імені М. П. Драгоманова. Серія 19: Корекційна педагогіка та спеціальна психологія, 29, 202-207.

9. Міщиха, Л.П. (2016). Творчий профіль особистості. Психологічні перспективи, 27, 102-113.

10. Caprara, G., Barbaranelli, C. And Zimbardo, Ph. (1999). Personality Profiles and Political Parties. Political Psychology, 20, 1, 175-197.

11. Personality profile (2009). https://www.dictionary.com/browse/personality-profile.

12. Percy, L. (1976). A Look at Personality Profiles and the Personality-Attitude-Behavior Link in Prediction Consumer Behavior. Advances in Consumer Research. Eds. Beverlee B., 3, 119-124.

13. Saroglou, V. (2010). Religiousness as a Cultural Adaptation of Basic Traits: A Five-Model Factor Perspective. Personality and Social Psychology Review, 14 (1), 108-125.

14. Stevens, J. P. (2009). Applied Multivariate Statistics for the Social Sciences: Analyses with SAS and IBM's SPSS. 5-th ed. London: Routledge.

\section{REFERENCES}

1. Aimedov, K. V., Morvaniuk, H. V. (2015). Typy osobystisnykh profiliv cholovikiv ta zhinok, khvorykh na paranoidnu formu shyzofrenii [Types of Personality Profiles of Men and Women Suffering from Paranoid Schizophrenia]. Psykhiatriia, nevrolohiia ta medychna psykholohiia [Psychiatry, Neurology and Medical Psychology], 2, 1, 10-14. (ukr.).

2. Butuzova, L. P., Sydorenko, N. I. (2014). Osobystisnyi profil usvidomliuvanoi samorehuliatsii povedinky maibutnikh pedahohiv [Personality Profile of Aware Self-Regulation of Future Teachers Behavior]. Nauka i osvita. Psykholohiia [Science and Education. Psychology Series], 5, 116-121. (ukr.).

3. Demchuk, O. A. (2016). Osobystisnyi profil samostavlennia v strukturi Ya-kontseptsii studentiv iz vysokym rivnem bezporadnosti [Personal Profile of Self-attitude in the Structure of Self-Concept of Students with High Level of Helplessness]. Psykholohichni perspektyvy [Psychological Prospects], 28, 107-119. (ukr.).

4. Zotova, L. M. (2012). Profil nevrotychnykh skhylnostei yak osobystisnyi faktor, shcho vyznachaie vnutrishniu kartynu zdorovia v studentiv [Profile of Neurotic Bents as the Personal Factor Defining the Internal Picture of Hearth at Students]. Visnyk Kharkivskoho natsionalnoho pedahohichnoho universytetu imeni H. S. Skovorody. Psykholohiia [Visnik of V. N. Karazin Kharkiv National University. Psychology Series], 44 (1), $79-92$. (ukr.).

5. Karpenko, Z. (2018). Aksiolohichna psykholohiia osobystosti. 2-he vyd., pererob., dopovn. [Axiological Psychology of Personality. 2d ed., addition.]. Ivano-Frankivsk. (ukr.).

6. Klymyshyn, O. I. (2010). Psykholohiia dukhovnosti osobystosti: khrystyiansky-oriientovanyi pidkhid [Psychology of Personality Spirituality: Christian-Oriented Approach]. Ivano-Frankivsk: Hostynets. (ukr.).

7. Leshchyna, I. V. (2012). Henderni osoblyvosti osobystisnoho profiliu u studentiv z nepsykhotychnymy psykhichnymy rozladamy [Gender peculiarities of personal profile at students with non-psychotic mental disorders]. Ukrainskyi visnyk psykhonevrolohii [Ukrainian Journal of Psychoneurology], 20, 3, 193-194. (ukr.).

8. Martynenko, I. V. (2015). Kharakterystyka osobystisnoho profiliu starshoho doshkilnyka z systemnymy porushenniamy movlennia [Description of the Personal Profile for the Elder Preschooler with System Speech Disorders]. Naukovyi chasopys Natsionalnoho pedahohichnoho universytetu imeni M. P. Drahomanova. Seriia 19: Korektsiina pedahohika ta spetsialna psykholohiia [Scientific Journal of M. P. Dragomanov National Pedagogical University. Series 19: Correctional Pedagogy and Special Psychology], 29, 202-207. (ukr.).

9. Mishchykha, L. P. (2016). Tvorchyi profil osobystosti [Creative Personality Profile]. Psykholohichni perspektyvy [Psychological Prospects], 27, 102-113. (ukr.).

10. Caprara, G., Barbaranelli, C. And Zimbardo, Ph. (1999). Personality Profiles and Political Parties. Political Psychology, 20, 1, 175-197.

11. Personality profile (2009). Retrieved from https://www.dictionary.com/browse/personality-profile.

12. Percy, L. (1976). A Look at Personality Profiles and the Personality-Attitude-Behavior Link in Prediction Consumer Behavior. Advances in Consumer Research. Eds. Beverlee B., 3, 119-124.

13. Saroglou, V. (2010). Religiousness as a Cultural Adaptation of Basic Traits: A Five-Model Factor Perspective. Personality and Social Psychology Review, 14 (1), 108-125.

14. Stevens, J. P. (2009). Applied Multivariate Statistics for the Social Sciences: Analyses with SAS and IBM's SPSS. 5-th ed. London: Routledge. 


\section{Nataliya Savelyuk \\ PERSONAL VALUE-SENSE PROFILES AT DIFFERENT LEVELS OF RELIGIOUS ACTIVITY: UNIVERSAL AND DIFFERENTIAL}

The concept of «personal profile» and empirically complements the value oriented sense dimensions of its construction are theoretically analyzes in the article. The psychodiagnostic tests used in the study were: "Questionnaire of religious activity» by D. Smirnov, «Express diagnostics of social values» by N. Fetiskin, V. Kozlov, G. Manuilov, and «Questionnaire of 16 P. F.» by R. Kettel. The mathematical processing of quantitative data was performed using Student's t-test and factor analysis by principal component method. By subtracting the quartiles, the primary sample of respondents was divided into four subgroups with different levels of religious activity, from the lowest to the highest.

The empirical study identified the following priority social values: at the lowest level of religious activity successful marriage, spending time with family and a few close friends; at the lower than average level-spending time with family, having a good marriage and a few close friends; at the above average level-spending time in the family, successful marriage, religion, at the highest level - religion, spending time with the family and meditating on God, praying. It is stated that at the higher levels of religious activity, the most significantly increases the religious values, as well as the values of communication with family and close friends, volunteering, intellectual selfdevelopment and healthy eating; increases to a lesser extent - sports exercises, involvement in social activities and acquaintance. The subjective appeal of exciting work / study, successful marriage and career does not change significantly.

The universal characteristic of personal value-senses profiles of both low-religious and high-religious subjects is determined by the higher gravity of critically-minded and liberal-minded individuals to attain high social and material status. Differentiating features are predictors of the desire of the individual for intellectual selfimprovement at different levels of religious activity, as well as his greater focus on narrow personal or wideranging social contacts.

Keywords: personal profile, values, religious activity, religious values. 